See discussions, stats, and author profiles for this publication at: https://www.researchgate.net/publication/328589712

\title{
LUDIC STRATEGIES IN MODERN ENGLISH-LANGUAGE MEDIATEXT
}

Article · January 2018

DOI: 10.32837/2312-3192-2018-11-71-77

1 author:

Irena Snikhovska

Zhytomyr State University

2 PUBLICATIONS 40 CITATIONS

SEE PROFILE 


\title{
LUDIC STRATEGIES IN MODERN ENGLISH-LANGUAGE MEDIATEXT
}

\author{
Irena Snikhovska ${ }^{1}$
}

\begin{abstract}
The article is devoted to the comprehensive study of the phenomenon of language play in modern English, performed in the context of the communicative-activity approach to the study of linguistic and speech phenomena. On the methodological basis of communicative-functional linguistics and cognitive linguistics, the cognitive-communicative nature of the language game is substantiated in the article. In view of the factors of the cognitive-discursive order, lexical-semantic means of constitution and realization of the ludic intentions of the language personality as the creator media text and their ludic strategies are singled out. In the current research, the division of the main operating methods of creating language play was worked out for the purpose of target tasks. These are based on the external and internal structure of the word: units of the external structure are phonemes, free and bound morphemes, word-formation constructs; the internal structure of the word is its meaning, the types of meanings and their connotations, their motivation, as well as various transformations of meanings. Consequently, the two types of ludisms are differentiated depending on their grounding on the external or internal structure of the word. The first class includes phonosemantic, word-formation and lexicogrammatical ludisms, and the second is represemted by lexico-semantic, phrase-semantic and phraseological ludisms.

The conclusion is made that from this perspective, language play appears as a process and result of the conscious linguistic activity of the individual, aimed at non-stereotypical variation of the form and content of the linguistic units on the playful level of communication in order to influence the emotional and/or intellectual sphere of the addressee. Language play is a manifestation of linguocreative thinking, which realizes the possibilities laid down in the linguistic sign. The basic principle of language play is the ability to establish associative relationships, which is an indicator of the creativity of the speech person. In the article it is proved that language play has a dual nature, combining features of both linguistic and speech phenomena.
\end{abstract}

\section{Keywords}

Language play, linguocreativity, playful (ludic) function of language, mass media, discursive activity, word, word outer structure, word inner structure.

1. Introduction. Modern active linguistic processes to a certain extent take place due to the intensification of the creative element in English discourse: this is manifested in the fact that innovation, language play and other forms of unconventional use of linguage encompass

\footnotetext{
1 Associate Prof., PhD. I. E. Snikhovska, Zhytomyr Ivan Franko State University, Velyka Berdychivska Str., 40, 10008-Zhytomyr, Ukraine, Email: irena29@gmail.com. ORCID ID: 0000-0001-6775-274X

${ }^{2}$ Gridina 1996

${ }^{3}$ Iliasova, Amiri 2009

${ }^{4}$ Remchukova 2010

${ }^{5}$ Solganik 2005

${ }^{6}$ Zheltukhina 2003

${ }^{7}$ Arutyunova 2006

${ }^{8}$ Attardo 2001

${ }^{9}$ Caillois 2007

${ }^{10}$ Chiaro 1992

${ }^{11}$ Crystal 1998

${ }^{12}$ Giora 2003

${ }^{13}$ Gridina 1996

${ }^{14}$ Gruzberg 2002

${ }^{15}$ Karasik 2002

${ }^{16}$ Kostomarov 1994

${ }^{17}$ Nilsen 1978

${ }^{18}$ Nukhov 1997

${ }^{19}$ Sannikov 2002

${ }^{20}$ Sherzer 2002

${ }^{21}$ Snikhovska 2004

${ }^{22}$ Zemskaya 1983
}

new communicative spheres (eg., advertising and the Internet), thereby expanding the scope of creativity.

The dynamics of linguistic processes, determined both by extralinguistic and linguistic factors, in the modern communicative space is most fully reflected in the media. The range of linguistic means that provides the basic constructive principle of the organization of media texts is noticeably changing.

The activization of the scientific interest of linguists in the media can be observed nowadays because at the present stage they are the primary source of information. Under the influence of socio-political reforms, advertising and media texts at the turn of the XX-XXI centuries have undergone dramatic changes.

The description of these changes is in line with such topical directions of modern linguistics as linguistic influence, linguistics of advertising, media linguistics of creativity, within the framework of which, in particular, the linguistic and educational components of the media are also studied [Gridina ${ }^{2}$; Ilyasova, Amiri'; Remchukova ${ }^{4}$; G. Solganik ${ }^{5}$, Zheltukhina ${ }^{6}$.

The phenomenon of language play has become the subject of a number of lingophilosophical, logical-semantic, functional-communicative, and linguocognitive [Arutyunova ${ }^{7}$, Attardo $^{8}$, Caillois ${ }^{9}$, Chiaro $^{10}$, Crystal ${ }^{11}$, Giora ${ }^{12}$, T. Gridina ${ }^{13}$, Gruzberg $^{14}$, Karasik ${ }^{15}$, Kostomarov ${ }^{16}$, Nilsen ${ }^{17}$, Nukhov ${ }^{18}$, Sannikov ${ }^{19}$, Sherzer ${ }^{20}$, Snikhovska ${ }^{21}$, Zemskaya ${ }^{22}$, etc.] studies on the empirical data of different languages. As of late, we observe a keen interest to linguistic creativity, and in particular to generation, 
modeling of the language play and ludic style, ludic discourse, etc. Thus, the presented article belongs to the works that analyze the phenomenon of language play as proposed by T. Gridina: "a form of linguocreative thinking exploiting the mechanisms of associative switching of the usual stereotype of perception, creation and use of linguistic units, characterized by convention and intentionality - an intention toward creativity, experiment on the sign on the basis of various linguistic methods of its transformation and interpretation" 23 .

The topicality of the research is substantiated by the need to study the mechanisms of the linguistic creativity that were previously used predominantly for the purpose of enhancing the expressiveness of the text. As many researches demonstrate, as of late, language play is used as a means of influencing and manipulating the society through mass media $\left[\right.$ Smetanina $^{24}$, Ilyasova ${ }^{25}$, Yazyk i stil sovremennyh sredstv massovoy informatsii ${ }^{26}$, Zheltukhina ${ }^{27}$, Dotsenko ${ }^{28}$.

The subject of the study is the cognitive and discursive mechanisms of language play in the mass media discourse, and the object of the study is language play, realized and verbalized in a variety of ways.

The purpose of the study is to highlight the linguistic and cognitive characteristics of the language play phenomenon in the media text, as a product of the creative activity of language personality and a means of reflecting the linguocultural concepts in the media.

The purpose of the study stipulates the following tasks:

- to address the place and role of language play in the creative human activity and to reveal the specificity of language play as a phenomenon of both language and speech;

- to identify and describe the cognitive and discursive characteristics of the language play;

- to analyze the operational methods of the language play on different levels of the language.

Background and motivations. Linguocreativity and the phenomenon of language play has long been in the field of view not only of linguists, but also of philosophers, anthropologists, culturologists, and cognitivists.

\footnotetext{
${ }^{23}$ Gridina 1996

${ }^{24}$ Smetanina 2002

${ }^{25}$ Ilyasova 2017

${ }^{26}$ Yazyk i stil sovremennyh sredstv massovoy informatsii 2007

${ }^{27}$ Zheltikhina 2003.

${ }^{28}$ Dotsenko 1997

${ }^{29}$ Huizinga 1949

${ }^{30}$ Kosmeda 2013

${ }^{31}$ Huizinga 1949

${ }^{32}$ Huizinga 1949

${ }^{33}$ Gridina 1996
}

The play concept of culture was formed in the works of foreign researchers of the early XXth century, in particular J. Huizinga's, who is the author of the theory of culture as a play ("Culture arises and unfolds in and as play, ... culture itself bears the character of play" ${ }^{29}$. In his groundbreaking work "Homo ludens. A study of the play-element in culture" (1938) a fundamentally new view of the activities of people was presented, which rests on the understanding of any human action as a play-element. In linguistics, this concept was embodied in the distinction of the game as a special type of discourse, which is regarded as "the space of creation and the perception of artistic texts" ${ }^{\prime \prime 3}$.

In J. Huizinga's classic work the play is presented as the basic principle of the development and functioning of culture, society and language: "The great archetypal activities of human society are all permeated with play from the start. Take language, for instance [...] allows him to distinguish, to establish, to state things; in short, to name them and by naming them to raise them into the domain of the spirit" 31 . At that, according to the scholar, the origins of the ludic character can be seen in the language, in particular in the language play: "In the making of speech and language the spirit is continually "sparking" between matter and mind, as it were, playing with this wondrous nominative faculty. Behind every abstract expression, there lie the boldest of metaphors, and every metaphor is a play upon words. Thus in giving expression to life man creates a second, poetic world alongside the world of nature"32

The integration of the play concept of the culture of humankind is possible in discursive human activity, within which we consider the implementation of mass media communication/interaction. From this perspective, the techniques used by language play are cognitive mechanisms of semantic compression in conjunction with linguistic experiment, testing the possibilities of language - on the one hand, and own erudition, a sufficient level of linguistic and extralingual knowledge, emotional intelligence - on the other. H. Gadamer's dialectic notion of play suggests that, like any game, language play is a behavior in the field of possibilities that involves knowledge of a system of rules that may be deliberately violated only if the system knows the limits of the permissible, because "the game itself plays as well, involving the players".

Language play has a discursive nature and is distinguished by the intention of linguistic units' form / content variation based on their association-building potential ${ }^{33}$. From such standpoint, the language system allows for the freedom of manifestation of the linguo-creativity of the person, so understanding of the play beyond the limits of creativity is impossible, therefore, it gives grounds to consider language play as a form of manifestation of the crea- 
tive ability of the person. In the scope of linguistics of emotions V. Shakhovskyi emphasizes that language play is a highly intellectual form of expression of emotions, in this phenomenon the "emotional intelligence" of both (re)producer of language play and its recipient is reflected ${ }^{34}$.

The concept of ludic discourse or play element of text creation is being ever more frequently used by critical theorists in modern discourse studies (Borbotko $^{35}$, Gridina ${ }^{36}$, Karasik ${ }^{37}$, Kosmeda ${ }^{38}$, Norman ${ }^{39}$, Sannikov $^{40}$, etc.), while broadening it from belle lettres style to the space of modern communication in general and interpreted as "a complex communicative phenomenon in which the information represented is structured in the form of a game, expresses the corresponding idea by simulating the game, resulting in a situation of ludic communication in the process of mutual interaction of the speakers - the addressee and the addresser, that are tuned to the ludic tone of communication, actualize the models of light-hearted behavior adopted in each particular linguistic culture"41. In this regard, mass media communication is also one of the manifestations of ludic discourse and can be characterized in terms of human ludic activities.

2. Methodology. In the article, we used both general scientific methods of induction, deduction, analysis and synthesis to address the research. Besides, the descriptive method with its main components (observation, interpretation and generalization) was applied. The main theoretical positions were evaluated and processed with the help of a special method of semantic-structural analysis of examples of the language play of the word-formation level, which appeared in the language of mass media as a result of blending or telescopic word-formation.

It should be noted, that the integral application of structural-systemic, cognitive-semantic, and communicative-functional approaches to the study of linguistic matter makes it possible to consider the phenomenon of language play not only and not as much as the manifestation of unconventional use of the verbal sign, but also as a specific form of intellectually and emotionally marked speech activity. An integrative approach to the interpretation of language and speech phenomena will involve the interdisciplinary application of traditional and new research methods - component, conceptual, contextual, etc.

\footnotetext{
${ }^{34}$ Shakhovskiy 2003

${ }^{35}$ Borbotko 2007

${ }^{36}$ Gridina 1996

${ }^{37}$ Karasik 2002

${ }^{38}$ Kosmeda 2013

${ }^{39}$ Norman 2006

${ }^{40}$ Sannikov 2002

${ }^{41}$ Kosmeda 2013
}

Our observations have shown that language play is especially vividly used in English-language media discourse, since modern media have developed effective lingual and extralingual tools and methods of mass impact on the audience worldwide. The reason for such a high frequency of the ludic use of linguistic forms is their huge mass impact, since it is in the printed and electronic media that the political and ideological impact on the addressee as an object of forming a certain public opinion in implemented. This objective is often solved with the help of unconventional lingual coinages, or paradoxically constructed phrases in which a game with linguistic forms and structures can be traced.

Under current circumstances, the communication is characterized by a strong confrontation of ideologies and influential political and economic world groups, and thus the devices of language play are considered as a means of influencing the society through the media. The formative and semiotic possibilities of the English language are expedient for the creation of linguistic means possessing special impact, namely a phenomenon of the language play, which allows the addresser of the message to form the necessary addressee's attitude to the information presented.

Thus, the concept of mass media communication as a ludic reality lies at the foreground of our research. Within the framework of this concept, mass media communication and mass media discourse are interpreted as a manifestation of the ludic essence of human activity, which is realized through a number of parameters.

The material of the study are mass 364 media text fragments containing language play phenomena, evaluated and processed with the help of a special method of semantic-structural analysis of examples. The sources of the research were 10 contemporary weekly and daily British and US periodicals belonging to both quality press and popular papers.

The use of the cognitive approach to the study of the phenomenon of language play allows for the interpretation of non-standard speech use not as errors, but as specific operations on knowledge structures, confirms the presence in word consciousness of the word-building models and frames with significant heuristic and epistemological potential.

3. Results. Such characteristics of the media as the mass dissemination of information, the direction of influence, publicity largely precondition their ability of being an effective means of speech impact. It is carried out with the help of linguistic means, which, in combination with extralinguistic means, certain methods of organizing the text, structuring and presenting the information form a strategy of speech impact. Given the need for a constant search for expressive, emotional and figurative means to influence the reader, journalists face the need to create linguistic and creative phenomena. Modern headlines and slo- 
gans have an increased semantic density and expressiveness, so the study of their linguistic and creative potential involves a description of their expressiveness. The authors of modern media texts use such means of expression that provide not only informational but also emotional and expressive saturation of the text. Such an aspiration was conditioned by the focus of the authors of media texts, copywriters towards the active use of neologisms, nonce words, language play, the transformations of phraseologisms, precedential phenomena, and the like.

In the phenomenon of language play, consisting in non-standard use of linguistic units or categories and realizing the creative agility of the speaker, the associative potential of the word is reflected in full. Among the expressive possibilities of language play in modern media texts, not only comic ones are distinguished, due to the creation of a comic effect as a stylistic goal that is traditionally studied, but no less significant is the aesthetic effect, which is characterized by drawing the attention to the linguistic form itself. The phenomenon of language play together with the above-mentioned possibilities, realizes a number of implicit, persuasive, suggestive functions associated with its use in mass-media discourse.

The creative impulse of the language play encourages finding possible methods for bringing out the sign beyond the system-defined model of the context of its design and perception. There is the whole range of means derived from the asymmetry of the verbal sign aimed at creating non-standard utterances with the help of the language resources: homonymy, polysemy, grammatical ambiguity, associative connections of words. In addition, the language play makes it possible to make the utterance more succinct and potent, containing several meanings, each of them being able to realize a certain function: nominative, evaluative, stylistic, associative, etc., for example, "No police state", demanded one placard. "Freedom not fear$d^{\prime} m^{\prime}$, read another" ${ }^{\prime 2}$, allows to interpret the creative innovation "feardom, $n$. - the state of living in fear or being subject to laws and policies based on fear".

The dynamics of the norm in the media, the full implementation of the systemic potential of the language system in modern media texts, the interest they represent in terms of studying the theory and practice of linguistic influence - all this provides unfading attention to this area of communication. It is note-

\footnotetext{
${ }^{42}$ The Economist, March 19, 2015

${ }^{43}$ Yazyk i stil sovremennyh sredstv massovoy informatsii 2007

${ }^{44}$ The Economist, January 15, 2015

${ }^{45}$ The Evening Herald, April 30, 2014

${ }^{46}$ Mamamia, August 10, 2013

${ }^{47}$ U.S. News \& World Report, August 28, 2006

${ }^{48}$ TakePart, July 22, 2013

${ }^{49}$ Confidential, December, 2011
}

worthy that the linguistic components are equally characteristic of the yellow (Mamamia, Netbit Host, TakePart, The Village Voice, etc.) and for the "quality" press (The Economist, The Times, the US News \& World Report, The Evening Herald, etc.).

Obviously, in the the creation of new nominations the author's individual role is crucual, as well as lexical and syntactic combinability, which makes it possible to highlight the main functions of the language from a new angle of view. It is worth noting that modern linguistics (in particular, linguistics of creativity) generates an idea of a creative function, which is based on linguocreative thinking, which prompts an individual to use the potential of linguistic units ${ }^{43}$.

For contemporary English-language media texts, such methods of creating a ludic effect as the play of polisemantic and homonymous words, the creation of occasionalisms, neologisms, and paronymic attraction are typical. Nonce words are occasional, individual in nature, but in English, they can be systematized according to word-building means, with the help of which these ludic coinages are created, since the author, in one way or another, relies on formal and structural models when creating a new word. For example, "but anything can take a hashtag, and dictionary-makers are not going to include" \#dictionary "next to" dictionary "," \#lexicography "next to" lexicography ", and so on. Something has to change in the real world for "hashtagification" to lead to word-hood"44.

Our attention was concentrated on compounding as one of the most commonly used word-building patterns in English. A typological pattern of word composition is implemented by compound words derived from nouns, adjectives, adverbs and verbs, eg: bride + chill (cf. bridezilla): "My sister keeps calling me a Bridechilla because I'm so chilled about everything. It's all really very relaxed"45; Anita is a bridechilla, the type of bride who wants her and her fiancé's day to be special but not at the expense of going crazy, broke or sending friends and family running for cover ${ }^{46}$.

One of the variations of play on words, reflected in the English language by contamination, rests on this model. It is specifically in the case of contamination that the cognitive capacities of the language play in modern media texts occur in the most concentrated form, for example: Wikipedia + literate; Wikipedia + reality: Are you wikiliterate? If not, start studying! For one thing, "wikiality," a Stephen Colbert-inspired "word of the year," is a password that signals you are an irony insider. But beyond that, the wiki website model, popularized by Wikipedia, is also emerging as a hot business tool $^{47}$; cold + landscape: The gigantic tank farms of Tropicana and Citrusuco, the world's largest orange juice producer, occupy one particular corner of the coldscape, with its own specific architecture and quirks ${ }^{48}$; Cointreau + metropolitan: Dita von Teese presents Cointreaupolitan. "That's the way I love it" ${ }^{\text {"49 }}$; Cointreau + controversial: "The big ques- 
tion is; are you cointreau-versal enough? Cointreau. Be Cointreauversal" ${ }^{50}$; cooking + footprint: What do you call the impact you make on the planet when you cook? It's your "cookprint"- the entire chain of resources used to prepare meals, and the waste produced in the process ${ }^{51}$; Bluetooth + hijacking The tourist was "bluejacked" - surreptitiously surprised with a text message sent using a short-range wireless technology called Bluetooth ("Cell phone messaging takes a mischievous turn" $)^{52}$; sapient + sexual: "Sapiosexual" is a relatively new word that refers to a person who is erotically attracted to intelligence ${ }^{53}$.

The language play in contemporary English-language media is characterized by implicit possibilities, in view of which it can carry certain implications associated with the conceptual representations of the sociocultural community that are part of the picture of the world, which exists in the collective consciousness of a particular language community. Obviously, language play is a ubiquitous phenomenon in the discourse of the mass media, gaining the potential to express the moods and expectations with regard to actual events.

The material analysed has demonstrated that the achievement of the perlocutive effect of using language play the English-language mediatext, a wide range of techniques is employed involving the means of all levels of the language system, but basically all of these techniques are grounded on the external and internal structure of the word. The most productive was the use of convergent techniques - a combination of techniques of both types. For example, "The Foresight Saga" - phonosemantic pun + allusion (playing on the character's surname), "Ocean warning"; "Crime a and Punishment" 54 - substitutive word formation + phraseosemantic allusion.

Consequently, for the language play, resources of all levels of language are used to a varying degrees. In order to achieve the pragmatic effect, a wide range of tools is used, which, in all their diversity, can be broken down to two classes in accordance with the perception of the internal and external structure of the word.

The main operating methods of creating a ludic lingual unit (a ludism) are based on the external and internal structure of the word. Units of the external structure are phonemes, free and bound morphemes, word-formation constructs; the internal structure of the word is its meaning, the types of meanings and their connotations, their motivation, as well as various transformations of meanings.

\footnotetext{
${ }^{50}$ Netbit Host, November 26, 2014

${ }^{51}$ New Green Basics, February 26, 2008

${ }^{52}$ The Times, November 21-27, 2012

${ }^{53}$ The Village Voice, November 21, 2012

${ }^{54}$ The Economist, March 3, 2014

${ }^{55}$ Doskock 1996

${ }^{56}$ Cook 1997
}

In the current research the two types of ludisms are differentiated depending on their grounding on the external or internal structure of the word. The first class includes phonosemantic, word-formation and lexico-grammatical ludisms, and the second is represemted by lexico-semantic, phrase-semantic and phraseological ludisms.

In general, in a ludism can be traced the actually existing language relations and trends that determine the appearance of the corresponding transformation and interpretation of a sign. All methods of creating a ludism show the expansion of associative connections in speech under the conditions of realizing of the creative intention. Asystemic connections generate ludisms on the basis of systemic relationships, and paradoxical semantic ambiguity is created on the basis of establishing a correlation between the ludism and its lingual prototype. Thus, the associative linguocognitive strategy of language play is the modeling and decoding of non-standard code and is conditioned both by operational linguistic mechanisms and by specific linguistic techniques.

4. Conclusions. It is possible to draw the following inferences from the current research of language play on the sources of modern periodicals of English-speaking countries belonging both to the quality and to the popular press.

In general, our observations indicate that mechanisms, means and methods of producing ludic phenomena in modern English determine the ways and means of transforming linguistic units into a unit of speech. The basis of the mechanism of ludisms creating primarily is deviation from the norms of use of linguistic units, the consequence of which is the emergence of the effect of unexpectedness and contradiction. It is clear from the research that occasional change in the form and content of linguistic units in ludic situations is determined by the cognitive-pragmatic factors of speech. In our view, the communicative-functional approach to the phenomenon of language play reveals its interconnection and interdependence in speech interaction on the situation of discourse and the purposes of communication. The key characteristics of language play are its ludic spirit, meeting the need for communication, the playful intent, the desire to realize the aesthetic function of speech [Doscock $\left.{ }^{55}, \mathrm{Cook}^{56}\right]$. As we can see, ludisms creation has a communicative-pragmatic goal-setting and can serve as an effective means of speech influence.

The research also has shown that In order to achieve the perlocutive effect of using language-game phenomena in the English language, a wide range of techniques is used with the use of means of all levels of the language system, but all of these techniques are based on the external and internal structure of the word. The most productive was the use of convergent techniques - a combination of techniques of both types. 
The use of the cognitive approach to the study of the phenomenon of language play allows for the interpretation of non-standard speech use not as errors, but as specific operations on knowledge structures, confirms the presence in word consciousness of the word-building models and frames with significant heuristic and epistemological potential.
Representing a special form of linguocreative thinking of an associative nature, the language game is always aimed at using lingual techniques to emphasize the paradox between the standard form and/ or the value of the linguistic unit in the form of some new associative processing of lingual or extralingual knowledge.

\section{BIBLIOGRAPHY}

Арутюнова Н. Д. Виды игровых действий / Н. Д. Арутюнова // Логический анализ языка. Концептуальные поля игры. -

М. : Индрик, 2006. - С. 5-15.

Борботько В. Г. Принципы формирования дискурса : От психолингвистики к лингвосинергетике / В. Г. Борботько. М. : КомКнига, 2007. -288 с.

Гридина Т. А. Языковая игра: стереотип и творчество / Т. А. Гридина. - Екатеринбург : Изд-во Уральск. гос. пед. ун-та, 1996. -214 c.

Грузберг Л. А. Игра: слово и концепт / Л. А. Грузберг // Языковая игра как вид лингвокреативной деятельности. Формирование языковой личности в онтогенезе. - Екатеринбург : Изд-во Уральск. гос. пед. ун-та, 2002. - С. 28-29.

Доценко Е. Л. Психология манипуляции / Е. Л. Доценко. - М. : Прометей, 1997. - 340 с.

Желтухина М. Р. Тропологическая суггестивность масс-медиального дискурса: о проблеме речевого воздействия тропов в языке СМИ / М. Р. Желтухина. - Волгоград : Изд-во ВФ МУПК, 2003. - 656 с.

Земская Е. А. Языковая игра // Русская разговорная речь: Фонетика. Морфология. Лексика. Жест: В 2 ч. / Земская Е. А., Китайгородская М.В., Ширеев Е.Н. - Ч. 2. - М.: Наука, 1983. - С. 172-214.

Ильясова С. В., Амири Л. П. Языковая игра в коммуникативном пространстве СМИ и рекламы / С. В. Ильясова, Л. П. Амири. - Москва : Флинта, 2009. - 296 с.

Ильясова С. В. Словотворчество? Словоерничество? К оценке игровых стратегий в языке современных российских СМИ / С. В. Ильясова // Уральский филологический вестник. Серия: Язык. Система. Личность: лингвистика креатива. - 2017. C. $68-75$.

Кайуа Р. Игры и люди / Р. Кайуа // Игры и люди; статьи и эссе по социологии культуры. - М. : ОГИ, 2007. - С. 33-204.

Карасик В.И. Языковой круг: личность, концепт, дискурс / В. И. Карасик. - Волгоград : Перемена, 2002. - 477 с.

Космеда Т. А. Мовна гра в парадигмі інтерпретативної лінгвістики. Граматика оцінки. Граматична ігрема (теоретичне осмислення дискурсивної практики) / Т. А. Космеда, О. В. Халіман. - Дрогобич : Коло, 2013. - 228 с.

Костомаров В. Г. Языковой вкус эпохи. Из наблюдений над речевой практикой масс-медиа / В. Г. Костомаров. - М. : Педагогика-Пресс, 1994. - 248 с.

Норман Б. Ю. Игра на гранях языка / Б. Ю. Норман. - М. : Флинта: Наука, 2006, 344 с.

Нухов С. Ж. Языковая игра в словообразовании : (на материале лексики англ. яз.) : автореф. дис. ... д-ра филол. наук /

С. Ж. Нухов ; Моск. гос. ун-т им. М. В. Ломоносова. - М., 1997. - 39 с.

Ремчукова Е. Н. Некоторые коммуникативные и стилистические особенности креативных феноменов в СМИ / Е. Н. Ремчукова // ŽMOGUS KALBOS ERDVĖJE. - Nr. 6, Mokslinių straipsnių rinkinys. - Kaunas, 2010. - C. 466-471.

Санников В. 3. Русский язык в зеркале языковой игры / В. З. Санников. - М. : Языки славянской культуры, 2002. - 552 с.

Сметанина С. М. Медиа-текст в системе культуры. Динамические процессы в языке и стиле журналистики конца XX века /

С. М. Сметанина. - М. : Издательство Михайлова, 2002. - 384 с.

Сніховська I. Е. Механізми, засоби та прийоми мовної гри в сучасній англійській мові : дис. канд. філол. наук : 10.02 .04 /

Сніховська Ірена Едуардівна. - Житомир, 2004. - 212 с.

Солганик Г. Я. Язык современной публицистики / Г. Я. Солганик. - Москва : Флинта-Наука, 2005. - 232 с.

Шаховский В. И. Эмотивный код языка и его реализация / В. И. Шаховский . - Волгоград : Перемена, 2003. - 174 с.

Язык и стиль современных средств массовой информации / ред. Т. В. Маркелова. - М. : МГУП, 2007. - 476 с.

Attardo S. Humorous Texts: A Semantic and Pragmatic Analysis / S. Attardo. - Berlin, N.Y. : Mouton de Gruyter, 2001. - 232 p.

Chiaro D. The Language of jokes. Analyzing wordplay / D. Chiaro. - London/New York Routledge, 1992. - 124 p.

Cook G. Language Play, Language Learning / G. Cook // IELT Journal. - 1997. - Vol. 51. - P. 224-231.

Crystal D. Language Play / D. Crystal. - London : Penguin, 1998. - 249 p.

Doskock P. Happily Ever Laughter / P. Doskock // Psychology Today. - July-August, 1996. - P. 33-35.

Giora R. On Our Mind: Salience, Context, and Figurative Language / R. Giora. - Oxford University Press, Oxford, 2003. - 259 p. Huizinga J. Homo ludens: a study of the play-element in culture / J. Huizinga. - Routledge \& K. Paul, 1949. - 220 p.

Nilsen D. L. F. Language Play: An Introduction to Linguistics / D. L. F. Nilsen, A. P. Nilsen. - Rowley, Massachusets: Newbury House, 1978. - 249 p.

Sherzer J. Speech Play and Verbal Art / J. Sherzer. - Austin, TX : Texas University Press, 2002. - 198 p.

Confidential, December, 2011.

Mamamia, August 10, 2013.

Netbit Host, November 26, 2014.

New Green Basics, February 26, 2008.

TakePart, July 22, 2013.

The Village Voice, November 21, 2012.

The Evening Herald, April 30, 2014.

The Associated Press, November 13, 2003. 
The Economist, March 3, 2014.

The Economist, January 15, 2015.

The Economist, March 19, 2015.

U.S. News \& World Report, August 28, 2006.

\section{REFERENCES}

Arutyunova, N. D. (2006) Vidy igrovyh deystviy. In: Logicheskiy analiz yazyka. Kontseptualnye polya igry. Moscow: Indrik, pp. 5-15.

Borbotko, V. G. (2007) Principles of the formation of discourse: From psycholinguistics to linguosynergetics. Moscow: KomKniga. Gridina, T. A. (1996) Yazykovaya igra: stereotip i tvotchestvo. Ekaterinburg: Publishing house of Uralskiy State Pedagogical University.

Gruzberg, L. A. (2002) Igra: slovo i kontsept. In: Yazykovaya igra kak vid lingvokreativnoy deyatelnosti. Fromirovanie yazykovoy lichnosti v ontogeneze. Ekaterinburg: Publishing house of Uralskiy State Pedagogical University, pp. 28-29.

Dotsenko, E. L. (1997) Psihologiya manipulyatsii. Moscow: Prometheus.

Zheltuhina, M. R. (2003) Tropologicheskaya suggestivnost mass-medialnogo diskursa: k problem yazykovogo vozdeystviya tropov v yazyke media. Volgograd: Publishing house of VF MUPK.

Zemskaya, E. A. (1983) YAzykovaya igra. In: eds. Zemskaya EA, Kitaygorodskaya MV, Shireev EN Russian colloquial speech: Phonetics. Morphology. Vocabulary. Gesture. Part 2. Moscow: Nauka, pp. 172-214.

Ilyasova, S. V., Amiri, L.P. (2009) Yazykovaia igra v komunikativnom prostranstve SMI i reklamy. Moscow: Flinta.

Ilyasova, S. V. (2017) Slovotvorchestvo? Slovoernichestvo? K otsenke igrovyh strategiy v yazyke sovremennyh rossiyskih mass media. In: Uralskiy Filologicheskiy Vestnik. Series: Yazyk. Sistema. Lichnost: lingvistika kreativa, pp. 68-75.

Caillois, R. (2007) Igry i liudi. In: Igry I liudi: statti i esse po sotsiologii kultury. Moscow: OGI, pp. 33-204.

Karasik, V. I. (2002) Yazykovoy krug: Lichnost, Kontsept, Diskurs. Volgograd: Peremena.

Kosmeda, T.A., Khaliman, O. V. (2013) Movna gra v paradyhmi interpretatyvnoyi lingvistyky. Gramatyka otsinky. Gramatiychna ihrema (teoretychne okreslennya dyskursyvnoyi praktyky). Drohobych: Kolo.

Kostomarov, V.G. (1994) Yazykovoy vkus epohi. Iz nabliudeniy nad rechevoy praktikoy mass media. Moscow: Pedagogika-Press. Norman, B. Yu. (2006) Igra na granyah yazyka. Moscow: Flinta-Nauka.

Nukhov, S. Zh. (1997) Yazykovaya igra v slovoobrazovanii (na material leksiki angliyskogo yazyka). Dissertation. Moscow.

Remchukova, E. N. (2010) Nekotorye kommunikativnye i stilisticheskie osobennosti kreativnyh fenomenov v SMI. In: ŽMOGUS

KALBOS ERDVĖJE, Nr. 6, Mokslinių straipsnių rinkinys. Kaunas, pp. 466-471.

Sannikov, V. Z. (2002) Russkiy yazyk v zerkale yazykovoj igry. Moscow: Yazyki Slavyanskoy kultury.

Smetanina, S. M. (2002) Media-text v sisteme kultury. Dinamicheskie protsessy v yazyke i zhurnakistike kontsa XX veka. Moscow:

Izd-vo Mikhaylova.

Snikhovska, I. E. (2004) Mehanizmy, zasoby ta priyomy movnoi gry v suchasniy angliyskiy movi. Dissertation. Zhytomyr.

Solganik, G. Ya. (2005) Yazyk sovremennoi publitsistiki. Moscow: Flinta-Nauka.

Shakhovsky, V. I. (2003) Emotivniy kod yazyka i ego realizatsiya. Volgograd: Peremena.

Yazyk i stil sovremennyh sredstv massovoy informatsii (2007) / ed. T. V. Markelova. Moscow: MGUP.

\section{Анотація}

Статтю присвячено комплексному дослідженню явища мовної гри в сучасній англійській мові, виконаному в руслі комунікативно-діяльнісного підходу до вивчення лінгвальних і мовних реалій. На методологічній основі комунікативно-функціональної лінгвістики і когнітивної лінгвістики в роботі обгрунтована когнітивно-комунікативна природа мовної гри. 3 урахуванням факторів когнітивно-дискурсивного порядку в роботі виділені лексико-семантичні засоби конституювання і реалізації ігро-мовних установок мовної особистості. 3'ясовано, що основні операційні прийоми створення ігрем грунтуються на зовнішній та внутрішній структурі слова. Одиницями зовнішньої структури є фонеми, вільні та зв'язані морфеми, словотвірні конструкти; внутрішня структура слова - це його значення, види значень та їх відтінки, їх мотивованість, а також різного роду трансформації значень.

У роботі розрізняються два типи ігрем залежно від їх базування на зовнішній чи внутрішній структурі слова. До першого класу належать фоносемантичні, словотвірні та лексико-граматичні, до другого - лексико-семантичні, фразеосемантичні та фразеологічні ігреми.

У такий спосіб мовна гра постає як процес і результат свідомої лінгвокреативної діяльності індивіда, спрямованої на нестереотипне варіювання форми та змісту мовних одиниць на ігровому регістрі комунікації з метою впливу на емоційну та/ або інтелектуальну сферу адресата. Мовна гра $є$ проявом мовотворчого мислення, що реалізує закладені в лінгвальному знаку можливості. Основний принцип мовної гри полягає у здатності встановлювати асоціативні зв'язки, які $є$ показником креативності мовленнєвої особистості. У роботі доводиться, що мовна гра має двояку природу, поєднуючи в собі риси як мовного, так і мовленнєвого явищ.

\section{Ключові слова}

Мовна гра, лінгвокреативність, лудична функція мови, мас медіа, комунікативний акт, дискурсивна діяльність, слово, зовнішня структура слова, внутрішня структура слова. 